\title{
Photocycloaddition of aromatic and aliphatic aldehydes to isoxazoles: Cycloaddition reactivity and stability studies
}

\author{
Axel G. Griesbeck ${ }^{*}$, Marco Franke, Jörg Neudörfl and Hidehiro Kotaka
}

\section{Full Research Paper}

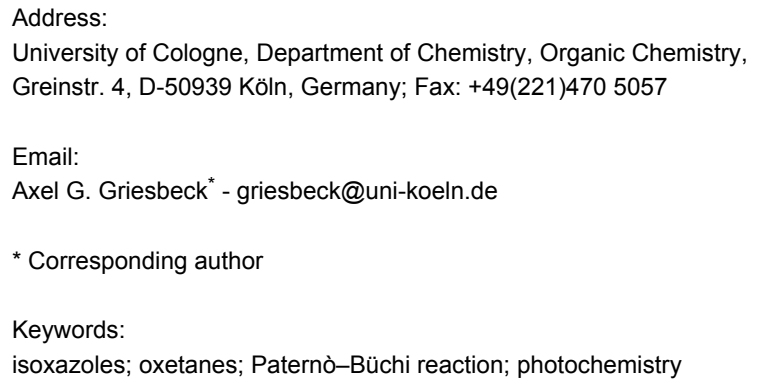

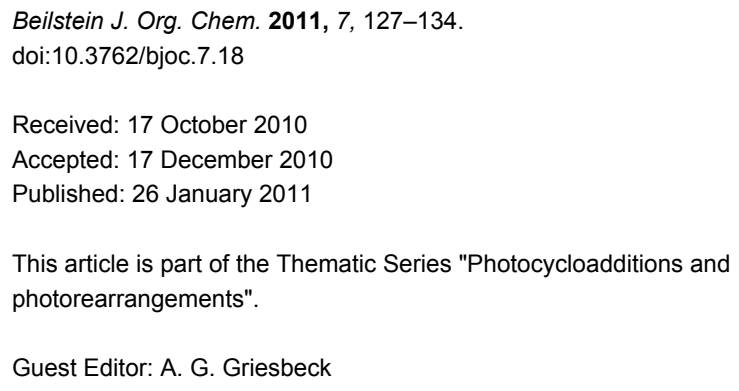

\begin{abstract}
The first photocycloadditions of aromatic and aliphatic aldehydes to methylated isoxazoles are reported. The reactions lead solely to the exo-adducts with high regio- and diastereoselectivities. Ring methylation of the isoxazole substrates is crucial for high conversions and product stability. The 6-arylated bicyclic oxetanes 9a-9c were characterized by X-ray structure analyses and showed the highest thermal stabilities. All oxetanes formed from isoxazoles were highly acid-sensitive and also thermally unstable. Cleavage to the original substrates is dominant and the isoxazole derived oxetanes show type T photochromism.
\end{abstract}

\section{Introduction}

Photochemical $[2+2]$ cycloadditions are among the most efficient photoreactions and are used in numerous synthetic applications due to the generation of highly reactive four-membered rings. An important example is the photocycloaddition of electronically excited carbonyl compounds to alkenes (Paternò-Büchi reaction). This reaction is a superior route to oxetanes, which can be subsequently transformed into polyfunctionalized products [1]. With regards to the regio- and diastereoselectivity of the Paternò-Büchi reaction, recent experimental and computational studies have brought about a remarkable increase in our understanding of this reaction. Especially the role of intermediary triplet 1,4-biradicals - their stability, lifetimes and intersystem crossing geometries - was crucial for a more sophisticated description [2-5], which also improved the synthetic significance of this reaction [6].

Previous publications have clearly demonstrated the versatility of the Paternò-Büchi reaction in various synthetic applications which gives rise to a multiplicity of different products. The photocycloaddition of furans to carbonyl compounds affords the corresponding $\beta$-hydroxy-1,4-diketones after hydrolysis of the primary photochemical products (photo aldol reaction) [7], 
whilst the reaction of oxazoles with carbonyl compounds is a convenient protocol for the stereoselective synthesis of $\alpha$-amino $\beta$-hydroxy ketones $[8,9]$ as well as highly substituted $\alpha$-amino $\beta$-hydroxy acids $[10,11]$.

The results on five-membered aromatic heterocycles published so far, however, has not included a study of isoxazoles as substrates in the Paternò-Büchi reaction. This class of heterocyclic compounds can be considered as masked $\beta$-amino ketones [12], and subsequently hydrolysed to the corresponding 1,3-diketones [13] or deaminated to yield Michael systems [14]. Thus, isoxazoles also appear to be important substrates for carbonyl-ene photocycloaddition due to possible applications in ring-opening transformations.

\section{Results and Discussion}

\section{Synthesis of the isoxazole substrates}

The substrates isoxazole (7a), 5-methylisoxazole (7b), 3,5dimethylisoxazole (7d) and 3,4,5-trimethylisoxazole (7e) were synthesized by reaction of the corresponding carbonyl compounds with hydroxylamine, while 3-methylisoxazole (7c) was obtained by the $[3+2]$-cycloaddition of acrylonitrile with the trimethylsilylester of aci-nitroethane 1 (Scheme 1). The reaction of acetylacetaldehyde with hydroxylamine gave $7 \mathbf{b}$, exclusively.

3,5-Diphenylisoxazole (7f) was prepared from acetophenone and methyl benzoate, followed by cyclization of the resulting diketone 4 with hydroxylamine. 5-Methoxy-3-phenylisoxazole (7g) and 5-(trimethylsilyloxy)-3-phenylisoxazole (7h) were synthesized from 3-phenylisoxazol-5-one (5) which was obtained by the reaction of ethyl benzoylacetate and hydroxylamine (Scheme 2). The preparation of aliphatic substituted isoxazole ethers however, could not be achieved, since the corresponding isoxazolones were unstable.

\section{Photochemistry of the isoxazoles $7 \mathbf{a}-\mathbf{h}$ : test reactions}

The isoxazoles $7 \mathbf{a}-\mathbf{e}$ were irradiated in the presence of benzaldehyde or propionaldehyde as model compounds for aromatic and aliphatic carbonyl compounds, respectively, at $\lambda=$ $300 \mathrm{~nm}$ in perdeuterated acetonitrile. ${ }^{1} \mathrm{H}$ NMR studies showed that the expected photoadducts were formed only from isoxazoles $\mathbf{7 d}$ and $\mathbf{7 e}$ with benzaldehyde (Scheme 3 and Table 1). In the presence of propionaldehyde no reaction was observed.

The use of a tenfold excess of aldehyde had no significant influence on the reaction. The use of a tenfold excess of the isoxazole, however, led to a considerable change in the reaction conversions (Table 2).

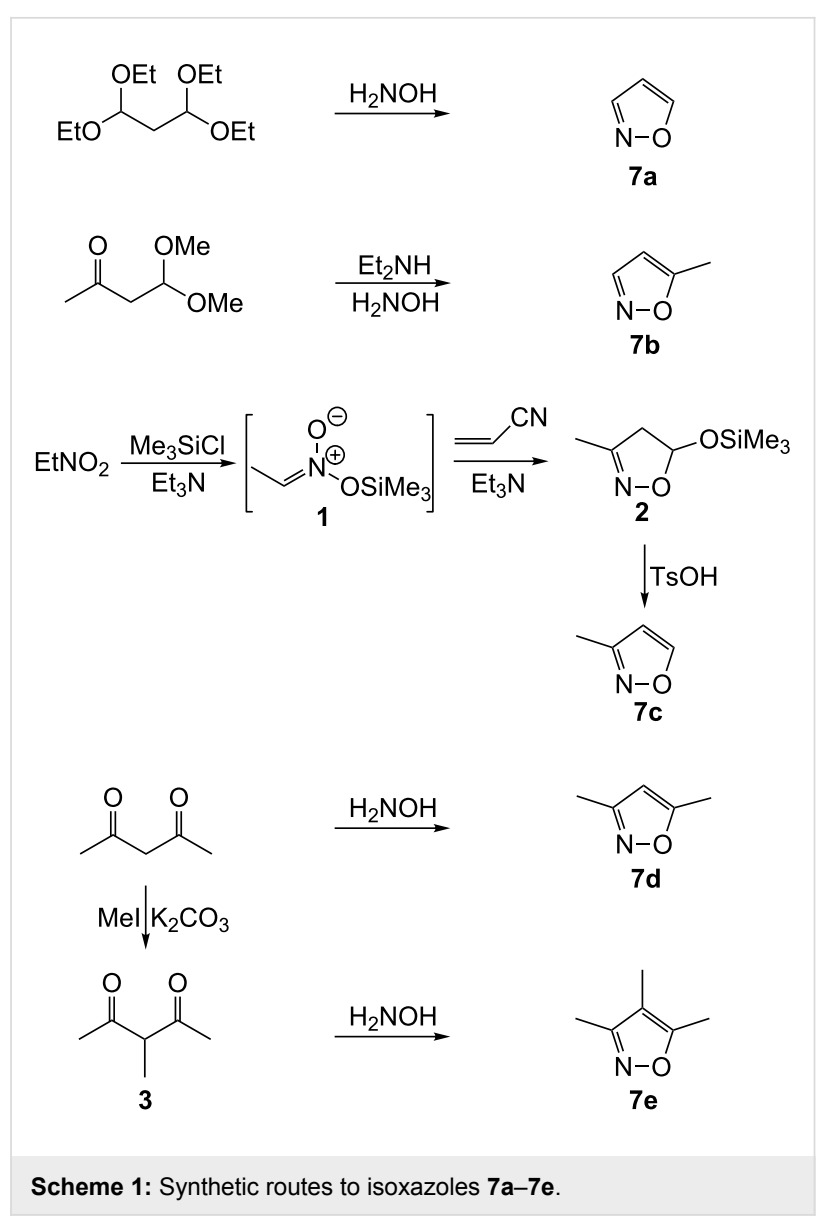

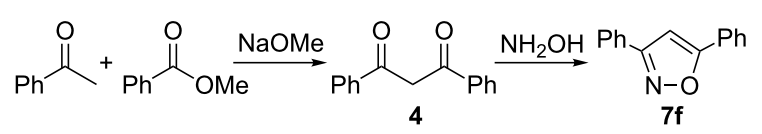

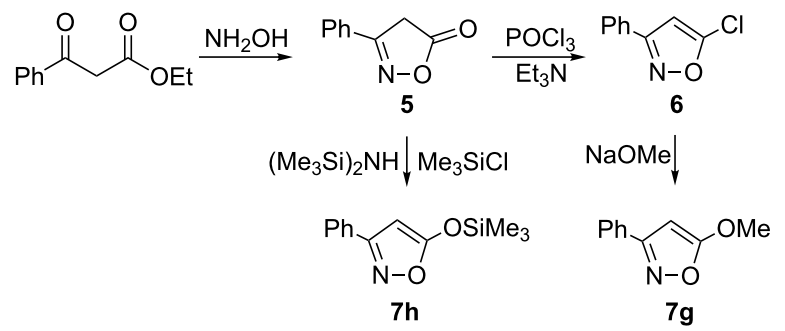

Scheme 2: Synthetic routes to isoxazoles $7 \mathrm{f}-\mathbf{7 h}$.<smiles>[R]c1noc([R6])c1[R]</smiles>

Scheme 3: Benzaldehyde photocycloaddition to $7 a-7 e$. 
Table 1: Irradiation of isoxazoles $7 a-e$ with benzaldehyde.

\begin{tabular}{ccccc} 
& $\mathrm{R}^{1}$ & $\mathrm{R}^{2}$ & $\mathrm{R}^{3}$ & conversion [\%] \\
\hline $\mathbf{7 a}$ & $\mathrm{H}$ & $\mathrm{H}$ & $\mathrm{H}$ & 0 \\
$\mathbf{7 b}$ & $\mathrm{H}$ & $\mathrm{H}$ & $\mathrm{Me}$ & 0 \\
$\mathbf{7 c}$ & $\mathrm{Me}$ & $\mathrm{H}$ & $\mathrm{H}$ & 0 \\
$\mathbf{7 d}$ & $\mathrm{Me}$ & $\mathrm{H}$ & $\mathrm{Me}$ & 13 \\
$\mathbf{7 e}$ & $\mathrm{Me}$ & $\mathrm{Me}$ & $\mathrm{Me}$ & 41 \\
\hline
\end{tabular}

abased on the formation of the photoproduct, by NMR (benzaldehyde isoxazole ratio $=1: 1$, irradiation time: $6 \mathrm{~h}$ ).

Table 2: Irradiations of $7 a-e$ with a tenfold excess of isoxazoles.

\begin{tabular}{ccccc} 
& $\mathrm{R}^{1}$ & $\mathrm{R}^{2}$ & $\mathrm{R}^{3}$ & conversion [\%] $^{\mathrm{a}}$ \\
\hline 7a & $\mathrm{H}$ & $\mathrm{H}$ & $\mathrm{H}$ & $<5$ \\
7b & $\mathrm{H}$ & $\mathrm{H}$ & $\mathrm{Me}$ & 15 \\
7c & $\mathrm{Me}$ & $\mathrm{H}$ & $\mathrm{H}$ & 10 \\
7d & $\mathrm{Me}$ & $\mathrm{H}$ & $\mathrm{Me}$ & 40 \\
7e & $\mathrm{Me}$ & $\mathrm{Me}$ & $\mathrm{Me}$ & 98 \\
\hline
\end{tabular}

${ }^{a}$ based on the formation of the photoproduct, by NMR (benzaldehyde isoxazole ratio $=1: 10$, irradiation time: $6 \mathrm{~h}$ ).

The conversion is highly dependent on the degree of substitution of the isoxazole used. In terms of frontier orbital interactions, the reason is the decreasing energy difference between the HOMO of the isoxazole and the SOMO of the excited aldehyde with increasing degree of substitution. Indirect proof of the increasing energy levels of the isoxazole-HOMO is provided from the corresponding ionization energies (Table 3) [15] which decrease with increasing substitution.

Table 3: Vertical ionization energies $\left(E_{i v}\right)$ of isoxazoles $7 a, 7 b$ and $\mathbf{7 d}$

\begin{tabular}{cc} 
& $E_{i v}[e V]$ \\
\hline $\mathbf{7 a}$ & 10.15 \\
$\mathbf{7 b}$ & 9.61 \\
$\mathbf{7 d}$ & 9.34
\end{tabular}

In contrast, the use of a tenfold excess of isoxazole in presence of propionaldehyde did not lead to an increased formation of the corresponding photoadducts. Only in the case of 7 e could traces of the expected photoproduct be detected $(<5 \%)$. Since the LUMO energy of propionaldehyde is larger than that of benzaldehyde, it can be assumed that the energy difference between the isoxazole-HOMO and the aldehyde-LUMO is too large to promote an efficient reaction.
The isoxazoles $7 \mathbf{f}-\mathbf{h}$ were treated similarly to $7 \mathbf{a}-\mathbf{e}$. However, in these experiments, the formation of the corresponding Paternò-Büchi products were not observed, neither in the presence of propionaldehyde nor in the presence of benzaldehyde. Instead, a reaction could be observed which also occurred both in the presence of a tenfold excess of aldehyde or without any aldehyde. This reaction was identified as the intramolecular ring contraction of $7 \mathbf{f}-\mathbf{h}$ to yield the corresponding azirines $8 \mathbf{a}-\mathbf{c}$ (Scheme 4) [16].

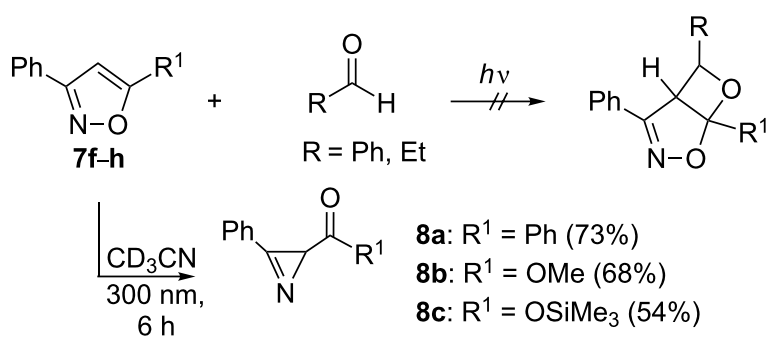

Scheme 4: Photochemical ring contraction of isoxazoles $7 \mathrm{f}-7 \mathrm{~h}$.

Surprisingly, in the absence of aldehydes as the potential reaction partners, the conversions of $\mathbf{7} \mathbf{f}-\mathbf{h}$ were significantly lower, suggesting the possibility of an energy transfer from the excited singlet or triplet aldehyde to the isoxazole.

Since the photolysis of $\mathbf{7 d}$ and $\mathbf{7 e}$ in presence of benzaldehyde showed the highest conversions, further irradiations were conducted in order to examine the effect of other aryl substituted aldehydes on reaction conversions (Scheme 5, Table 4).

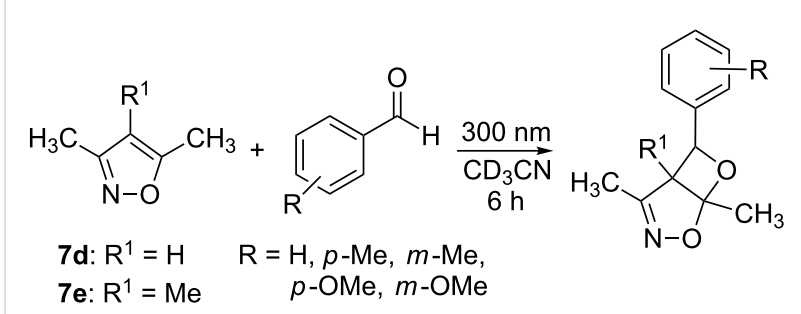

Scheme 5: Photocycloaddition of aromatic aldehydes to di- and trimethyl isoxazoles $\mathbf{7 d}$ and $7 \mathrm{e}$.

The reactions of 7e with $p$ - and $m$-tolualdehyde showed no change in the reaction conversions compared with benzaldehyde, whilst the conversions of $\mathbf{7 d}$ with these two aldehydes were considerably decreased. Irradiation of $\mathbf{7 d}$ and $7 \mathbf{e}$ with $p$ and $m$-anisaldehyde showed in all cases lower reaction conversions. 
Table 4: Photocycloadditions of $7 \mathrm{~d}$ and $7 \mathrm{e}$ with aromatic aldehydes.

\begin{tabular}{|c|c|c|}
\hline & $\mathrm{R}$ & conversion $[\%]^{a}$ \\
\hline $7 d$ & $\mathrm{H}$ & 40 \\
\hline “ & $p-\mathrm{Me}$ & 18 \\
\hline “ & $m-\mathrm{Me}$ & 18 \\
\hline “ & $p$-OMe & $<5$ \\
\hline$“$ & $m$-OMe & 0 \\
\hline $7 e$ & $\mathrm{H}$ & 98 \\
\hline “ & $p-\mathrm{Me}$ & 96 \\
\hline “ & $m-\mathrm{Me}$ & 92 \\
\hline “ & $p$-OMe & 65 \\
\hline “ & $m$-OMe & 19 \\
\hline
\end{tabular}

abased on the formation of the photoproduct (aldehyde - isoxazole $=$ $1: 10$, irradiation time: $6 \mathrm{~h}$ ).

\section{Synthesis of oxetanes from 7e and aryl substituted aldehydes}

The preparative photoreactions of $7 \mathbf{e}$ together with aryl substituted aldehydes were carried out in acetonitrile at $-10{ }^{\circ} \mathrm{C}$ in presence of $10 \mathrm{~mol} \%$ potassium carbonate (in order to neutralize traces of acid). In all cases, the regioisomers $9 \mathbf{a}-\mathbf{c}$ were formed with excellent (exo) diastereoselectivity ( $>$ 99:1, by ${ }^{1} \mathrm{H}$ NMR spectroscopy) in moderate yields and high purities (Scheme 6).

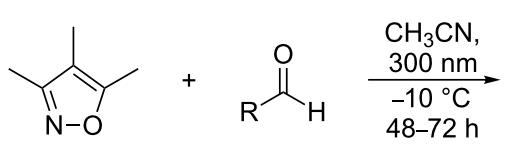

$7 e$

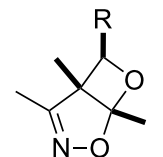

9a: $\mathrm{R}=\mathrm{Ph} \quad 50 \%$

9b: $\mathrm{R}=p$-Tol $35 \%$

9c: $R=m-$ Tol $65 \%$
Scheme 6: Preparative photocycloadditions of 7e with aromatic aldehydes.
The chemical structures of these bicyclic oxetanes were established on the basis of the NMR- and X-ray data (Figure 1) [17].

Both regio- and diastereoselectivity are in accord with the rules previously reported for the carbonyl-furan photocycloaddition [3]: High regiocontrol due to the FMO-controlled formation of the corresponding triplet 1,4-biradical and high stereocontrol due to SOC-controlled crossing from the triplet to the singlet surface $[4,5]$.

\section{Reaction behavior of the photoproducts $9 \mathbf{a}-\mathbf{c}$}

All bicyclic oxetanes obtained in the analytical photochemical experiments as well as in preparative studies (i.e., 9a-c) were acid labile and decomposed already in the presence of catalytic amounts of acid to give solely the starting materials. The photoproducts are also thermally labile and decompose at temperatures above approximately $100{ }^{\circ} \mathrm{C}$, again to give solely the starting materials. Thus, isoxazole-carbonyl photocycloaddition products constitute another class of photochromic T-type systems (Scheme 7) [18].

Hydrogenation of 9a by palladium/charcoal did not lead to the expected aminoketone 10, but to the enamino ketone $\mathbf{1 1}$ and benzyl alcohol, indicating decomposition of 9a back to the starting materials, followed by hydrogenation of these substrates (Scheme 8). Variations of reaction temperature $\left(-10^{\circ} \mathrm{C}\right)$, reaction time $(6 \mathrm{~h}, 1 \mathrm{~h})$ and solvent (ethanol, ethyl acetate) led to the same results.

Hydrogenation of 9a by Raney-nickel led to partial decomposition without any further reaction, whilst treatment with lithium aluminium hydride (3 equiv) yielded complex mixtures with benzyl alcohol as one of the main components. By contrast, no reaction could be observed in presence of sodium borohydride or sodium cyanoborohydride. Attempted reduction with sodium triacetoxyborohydride led to decomposition, probably due to
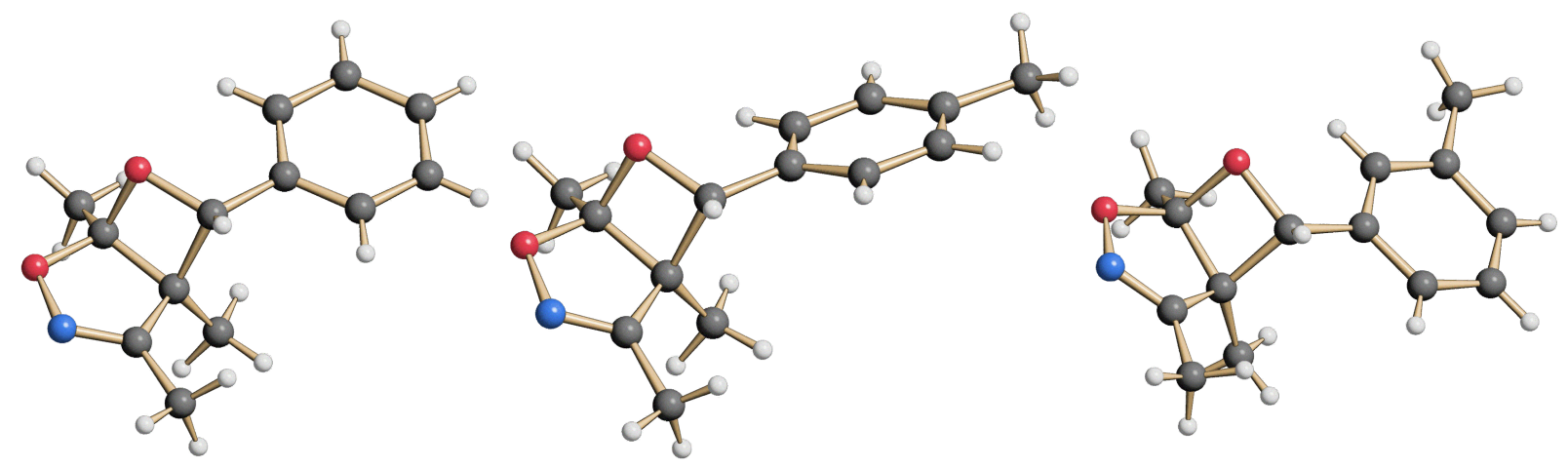

Figure 1: Structures of the photoproducts $9 a-9 c$ in the crystal. 


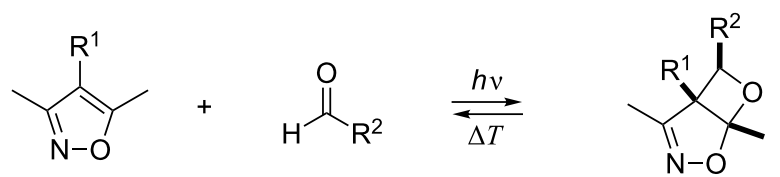

Scheme 7: T-type photochromism of isoxazole-aldehyde pairs.<smiles>CC1=NOC2(C)OC(c3ccccc3)C12C</smiles>

$9 a$

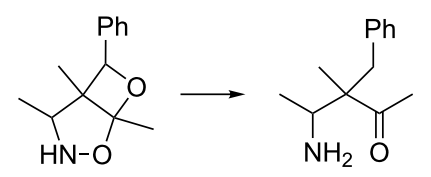

10

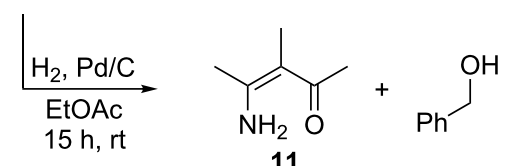

Scheme 8: Reductive cleavage of the trimethylisoxazole adduct $\mathbf{9 a}$

traces of acetic acid contained in the hydride reagent. Reductive treatment with sodium or samarium diiodide also led to decomposition of the photoproduct. Treatment of 9a with ethylmagnesium bromide did not lead to the alkylated photoproduct, but to partial decomposition into isoxazole $7 \mathrm{e}$ and benzaldehyde, while at $-78{ }^{\circ} \mathrm{C}$, no reaction could be observed. In contrast, the use of an excess of Grignard reagent ( 3 equiv) at $-78{ }^{\circ} \mathrm{C}$ again led to decomposition. The application of boron trifluoride at $-78^{\circ} \mathrm{C}$ also led to decomposition, followed by a normal nucleophilic attack of the Grignard reagent on the liberated benzaldehyde.

\section{Conclusion}

The photocycloaddition of electronically excited carbonyl compounds to isoxazoles is clearly less effective than with other five-membered aromatic or non-aromatic heterocycles (furans, thiophenes, pyrroles, oxazoles, dihydrofurans, dihydropyrroles) [1]. Only the combination of methylated isoxazoles and aromatic aldehydes is sufficient to allow photochemical addition and give adducts with sufficient thermal stability. It cannot be excluded at the current stage, that other combinations are also reactive in Paternò-Büchi chemistry resulting in thermally labile cycloadducts which thus have not yet been detected. Apparently, the bicyclic oxetanes isolated in this study are acid-labile and thermally unstable and thus constitute a new class of T-type chromophoric systems.

\section{Experimental}

General methods. All solvents were dried before use. Benzene, toluene and chloroform were distilled from $\mathrm{CaH}_{2} .{ }^{1} \mathrm{H} \mathrm{NMR}$ and ${ }^{13} \mathrm{C}$ NMR spectra were recorded on a Bruker AV 300 or a Bruker DRX 500 spectrometer. Melting points were determined with a Büchi melting apparatus (type Nr. 535) and are uncorrected. X-ray data collections were performed on a Nonius Kappa-CCD-diffractometer, using a monochromatic Mo $\mathrm{K}_{\alpha}$ $(0,71073 \AA)$ radiation. Combustion analyses were measured using an Elemental Vario EL Instrument. All irradiations were carried out in quartz vessels. Photochemical reactors LZ-C4 $(14 \times 3000 \AA$ lamps, $\lambda=300 \pm 10 \mathrm{~nm})$ and RPR-208 $(8 \times 3000$ $\AA$ lamps, $\lambda=300 \pm 10 \mathrm{~nm}$ ) were used for irradiations.

Trimethylsilyl ester of aci-nitroethane (1) [19]. Chlorotrimethylsilane $(43.20 \mathrm{~g}, 0.4 \mathrm{~mol}, 50.5 \mathrm{~mL})$ was added to nitroethane $(30.0 \mathrm{~g}, 0.4 \mathrm{~mol}, 28.7 \mathrm{~mL})$ and triethylamine $(40.40 \mathrm{~g}, 0.4 \mathrm{~mol}, 55.6 \mathrm{~mL})$ in benzene $(200 \mathrm{~mL})$. The mixture was stirred vigorously for $18 \mathrm{~h}$ at $\mathrm{rt}$, filtered and evaporated. The crude product was obtained as a yellow oil and used immediately without further purification.

3-Methyl-5-trimethylsilyloxy-2-isoxazoline (2) [19]. A mixture of acrylonitrile $(10.61 \mathrm{~g}, 0.2 \mathrm{~mol}, 13.2 \mathrm{~mL})$, triethylamine $(10.12 \mathrm{~g}, 0.1 \mathrm{~mol}, 13.9 \mathrm{~mL})$ and $\mathbf{1}(28.73 \mathrm{~g}, 0.2 \mathrm{~mol})$ in toluene $(90 \mathrm{~mL})$ was heated at $85^{\circ} \mathrm{C}$ for $1 \mathrm{~h}$. The solvent was removed and the crude product fractionated $\left(105-110{ }^{\circ} \mathrm{C}, 20 \mathrm{mbar}\right)$ to give $22.50 \mathrm{~g}(65 \%)$ of 2 as a colorless oil. ${ }^{13} \mathrm{C}$ NMR $\left(75.5 \mathrm{MHz}, \mathrm{CDCl}_{3}\right): 155.2\left(1 \mathrm{C}, \mathrm{C}_{\mathrm{q}}\right), 97.4(1 \mathrm{C}, \mathrm{CH}), 47.4(1 \mathrm{C}$, $\left.\mathrm{CH}_{2}\right), 12.9\left(1 \mathrm{C}, \mathrm{CH}_{3}\right), 0.0\left(3 \mathrm{C}, 3 \times \mathrm{CH}_{3}\right) .{ }^{1} \mathrm{H} \mathrm{NMR}(300 \mathrm{MHz}$, $\left.\mathrm{CDCl}_{3}\right): 5.80-5.77\left(\mathrm{dd}, 1 \mathrm{H},{ }^{3} \mathrm{~J}=5.8 \mathrm{~Hz}, 0.9 \mathrm{~Hz}, \mathrm{CH}\right)$, 3.04-2.96 (dq, $\left.1 \mathrm{H},{ }^{3} J=5.5 \mathrm{~Hz}, 0.8 \mathrm{~Hz}, \mathrm{CH}_{2}\right), 2.71-2.65$ (dq, $\left.1 \mathrm{H},{ }^{3} \mathrm{~J}=1.8 \mathrm{~Hz}, 0.8 \mathrm{~Hz}, \mathrm{CH}_{2}\right), 2.01\left(\mathrm{~s}, 3 \mathrm{H}, \mathrm{CH}_{3}\right), 0.15(\mathrm{~s}, 9 \mathrm{H}$, $\left.3 \times \mathrm{CH}_{3}\right)$.

3-Methylpentane-2,4-dione (3) [20]. A mixture of freshly distilled 2,4-pentanedione (28.03 g, $0.28 \mathrm{~mol}, 28.8 \mathrm{~mL}$ ), anhydrous potassium carbonate $(38.70 \mathrm{~g}, 0.28 \mathrm{~mol})$ and methyl iodide (49.68 g, $0.35 \mathrm{~mol}, 21.8 \mathrm{~mL})$ in acetone $(200 \mathrm{~mL})$ was refluxed in the dark for $20 \mathrm{~h}$ and then cooled to rt. The insoluble material was removed by filtration and washed thoroughly with acetone. The combined filtrate and acetone washings were then concentrated, extracted two times with chloroform, dried over magnesium sulfate and filtered. The solvent was evaporated and the residual oil distilled $\left(170{ }^{\circ} \mathrm{C}\right)$ to give $23.01 \mathrm{~g}$ (72\%) of $\mathbf{3}$ as a colorless oil. ${ }^{13} \mathrm{C} \mathrm{NMR}\left(75.5 \mathrm{MHz}, \mathrm{CDCl}_{3}\right)$ : $204.8\left(2 \mathrm{C}, \mathrm{C}_{\mathrm{q}}\right), 190.1\left(1 \mathrm{C}, \mathrm{C}_{\mathrm{q}}\right), 104.5\left(1 \mathrm{C}, \mathrm{C}_{\mathrm{q}}\right), 61.4(1 \mathrm{C}, \mathrm{CH})$, $28.4\left(2 \mathrm{C}, \mathrm{CH}_{3}\right), 23.0\left(1 \mathrm{C}, \mathrm{CH}_{3}\right), 20.9\left(1 \mathrm{C}, \mathrm{CH}_{3}\right), 12.2(1 \mathrm{C}$, $\left.\mathrm{CH}_{3}\right) .{ }^{1} \mathrm{H} \mathrm{NMR}\left(300 \mathrm{MHz}, \mathrm{CDCl}_{3}\right): 3.59$ (q, $1 \mathrm{H},{ }^{3} \mathrm{~J}=7.2 \mathrm{~Hz}$, $\mathrm{CH}), 2.06\left(\mathrm{~s}, 6 \mathrm{H}, 2 \times \mathrm{CH}_{3}\right), 1.97\left(\mathrm{~s}, 3 \mathrm{H}, \mathrm{CH}_{3}\right), 1.70(\mathrm{~s}, 1.5 \mathrm{H}$, $\left.\mathrm{CH}_{3}\right), 1.19-1.16\left(\mathrm{~d}, 3 \mathrm{H},{ }^{3} \mathrm{~J}=6.9 \mathrm{~Hz}, \mathrm{CH}_{3}\right)$. 
1,3-Diphenylpropane-1,3-dione (4). A mixture of acetophenone $(30.04 \mathrm{~g}, 0.25 \mathrm{~mol}, 29.2 \mathrm{~mL})$, methyl benzoate $(34.04 \mathrm{~g}$, $0.25 \mathrm{~mol}, 31.5 \mathrm{~mL})$, sodium methoxide (16.21 g, $0.3 \mathrm{~mol})$ and toluene $(300 \mathrm{~mL})$ was refluxed for $3 \mathrm{~h}$. The resulting solution was concentrated, cooled to $\mathrm{rt}$, poured into hydrochloric acid $(300 \mathrm{~mL}, 6 \mathrm{~N})$ and stirred for $30 \mathrm{~min}$. The aqueous mixture was extracted two times with toluene and the combined organic layers were neutralized with aqueous sodium hydroxide. The organic solution was then washed two times with water, dried over magnesium sulfate, filtered and evaporated. The resulting solid was recrystallized twice from ethanol to yield $6.34 \mathrm{~g}$ (41\%) of 4 as colorless crystals. ${ }^{13} \mathrm{C} \mathrm{NMR}\left(75.5 \mathrm{MHz}, \mathrm{CDCl}_{3}\right)$ : $185.6\left(2 \mathrm{C}, \mathrm{C}_{\mathrm{q}}\right), 135.4\left(2 \mathrm{C}, \mathrm{C}_{\mathrm{q}}\right), 132.4(2 \mathrm{C}, \mathrm{CH}), 128.6(4 \mathrm{C}$, $\mathrm{CH}), 127.1(4 \mathrm{C}, \mathrm{CH}), 93.0(1 \mathrm{C}, \mathrm{CH}) .{ }^{1} \mathrm{H}$ NMR $(300 \mathrm{MHz}$, $\left.\mathrm{CDCl}_{3}\right)$ : 8.03-7.99 (m, 4H, CH), 7.59-7.47 (m, 6H, CH), 6.87 (s, 1H, CH).

3-Phenylisoxazol-5-one (5) [21]. A mixture of ethyl benzoylacetate $(15.38 \mathrm{~g}, 80 \mathrm{mmol})$, hydroxylamine hydrochloride $(5.56 \mathrm{~g}, 80 \mathrm{mmol})$, potassium carbonate $(5.53 \mathrm{~g}$, $40 \mathrm{mmol})$, ethanol $(40 \mathrm{~mL})$ and water $(40 \mathrm{~mL})$ was stirred at $\mathrm{rt}$ for $15 \mathrm{~h}$. The solid was filtered, washed with water and extracted three times with ether. The combined organic layers were dried over magnesium sulfate, filtered and the solvent was evaporated. The residue was recrystallized from ethanol to give $9.21 \mathrm{~g}(71 \%)$ of 5 as colorless crystals. ${ }^{1} \mathrm{H}$ NMR $(300 \mathrm{MHz}$, $\mathrm{CDCl}_{3}$ ): 7.69-7.67 (m, 2H, CH), 7.54-7.46 (m, 3H, CH), 3.80 (s, $2 \mathrm{H}, \mathrm{CH}_{2}$ ).

3-Phenyl-5-chloroisoxazole (6) [22]. A mixture of 5 (4.84 g, $30 \mathrm{mmol})$ and phosphorous oxychloride $(16.3 \mathrm{~mL}, 175 \mathrm{mmol})$ was stirred at $0{ }^{\circ} \mathrm{C}$ and triethylamine $(3.37 \mathrm{~g}, 33 \mathrm{mmol}, 4.6 \mathrm{~mL})$ added slowly $\left(T<25^{\circ} \mathrm{C}\right)$. The solution was then heated at $120{ }^{\circ} \mathrm{C}$ for $2.5 \mathrm{~h}$ and the excess phosphorous oxychloride removed in vacuo. The brown residue was triturated with $100 \mathrm{~mL}$ iced water and extracted two times with ethyl acetate. The combined organic layers were dried over magnesium sulfate, filtered and the solvent was evaporated. The resulting residue was mixed with chloroform and the remaining solid removed by filtration. The solvent was again removed and the last step repeated with cyclohexane. After evaporation of the solvent, $3.18 \mathrm{~g}$ (59\%) of 6 was obtained as a yellow solid. ${ }^{13} \mathrm{C} \mathrm{NMR}\left(75.5 \mathrm{MHz}, \mathrm{CDCl}_{3}\right): 164.1\left(1 \mathrm{C}, \mathrm{C}_{\mathrm{q}}\right), 155.0\left(1 \mathrm{C}, \mathrm{C}_{\mathrm{q}}\right)$, $130.5(1 \mathrm{C}, \mathrm{CH}), 128.9(2 \mathrm{C}, \mathrm{CH}), 128.1\left(1 \mathrm{C}, \mathrm{C}_{\mathrm{q}}\right), 126.5(2 \mathrm{C}$, $\mathrm{CH}), 99.5(1 \mathrm{C}, \mathrm{CH}) .{ }^{1} \mathrm{H}$ NMR: 7.77-7.74 (m, 2H, $\left.\mathrm{CH}\right)$, 7.47-7.45 (m, 3H, CH), $6.47(\mathrm{~s}, 1 \mathrm{H}, \mathrm{CH})$.

Isoxazole (7a) [23]. Malonaldehyde tetraethyl acetal (22.03 g, $0.1 \mathrm{~mol}$ ) was added over a $30 \mathrm{~min}$ period to hydroxylamine hydrochloride $(7.64 \mathrm{~g}, 0.11 \mathrm{~mol})$ in water $(50 \mathrm{~mL})$ at $70{ }^{\circ} \mathrm{C}$. Heating was continued for $3 \mathrm{~h}$ and the resulting mixture distilled at $95{ }^{\circ} \mathrm{C}$ and a mixture of isoxazole, alcohol and water collected. The distillate was added dropwise to a solution of cadmium chloride $(18.30 \mathrm{~g})$ in water $(15 \mathrm{~mL})$. The resulting precipitate was filtered, washed with a little cold water and dried. The resulting solid was then suspended in water, heated to boiling and a mixture of isoxazole and water was obtained on distillation. The distillate (two phases) was extracted with ether, dried over magnesium sulfate and filtered. After evaporation of the solvent, $2.97 \mathrm{~g}(43 \%)$ of $7 \mathbf{a}$ was obtained as a colorless liquid. ${ }^{13} \mathrm{C} \mathrm{NMR}\left(75.5 \mathrm{MHz}, \mathrm{CDCl}_{3}\right)$ : $157.4(1 \mathrm{C}, \mathrm{CH}), 148.7$ (1C, CH), $103.2(1 \mathrm{C}, \mathrm{CH}) .{ }^{1} \mathrm{H}$ NMR $\left(300 \mathrm{MHz}, \mathrm{CDCl}_{3}\right): 8.36(\mathrm{~s}, 1 \mathrm{H}, \mathrm{CH}), 8.19(\mathrm{~s}, 1 \mathrm{H}, \mathrm{CH}), 6.26(\mathrm{~s}$, $1 \mathrm{H}, \mathrm{CH})$.

5-Methylisoxazole (7b). A mixture of acetylacetaldehyde (30.0 g, $0.227 \mathrm{~mol})$, diethylamine $(17.40 \mathrm{~g}, 0.238 \mathrm{~mol}$, $24.6 \mathrm{~mL})$ and methanol $(70 \mathrm{~mL})$ was heated at $65^{\circ} \mathrm{C}$ for $1 \mathrm{~h}$. Hydroxylamine hydrochloride ( $16.50 \mathrm{~g}, 0.238 \mathrm{~mol})$ of in water $(50 \mathrm{~mL})$ was then added dropwise and heating was continued for $2 \mathrm{~h}$. The solution was cooled to rt, extracted with ether, dried over magnesium sulfate and filtered. The solvent was evaporated and the residue fractionated $\left(78-80^{\circ} \mathrm{C}, 270 \mathrm{mbar}\right)$ to yield $4.94 \mathrm{~g}(26 \%)$ of $7 \mathbf{b}$ as a colorless liquid. ${ }^{13} \mathrm{C}$ NMR $\left(75.5 \mathrm{MHz}, \mathrm{CDCl}_{3}\right): 168.4\left(1 \mathrm{C}, \mathrm{C}_{\mathrm{q}}\right), 150.1(1 \mathrm{C}, \mathrm{CH}), 100.5$ $(1 \mathrm{C}, \mathrm{CH}), 11.6\left(1 \mathrm{C}, \mathrm{CH}_{3}\right) .{ }^{1} \mathrm{H}$ NMR $\left(300 \mathrm{MHz}, \mathrm{CDCl}_{3}\right): 8.02$ $(\mathrm{s}, 1 \mathrm{H}, \mathrm{CH}), 5.88(\mathrm{~s}, 1 \mathrm{H}, \mathrm{CH}), 2.33\left(\mathrm{~s}, 3 \mathrm{H}, \mathrm{CH}_{3}\right)$.

3-Methylisoxazole (7c) [24]. A solution of 2 (20.80 g, $0.12 \mathrm{~mol})$ and $p$-toluenesulfonic acid $(2.0 \mathrm{~g})$ in chloroform $(200 \mathrm{~mL})$ was refluxed for $2 \mathrm{~h}$. The resulting mixture was cooled to rt, washed with aqueous sodium bicarbonate and extracted several times with chloroform. The combined organic phases were washed several times with water, dried over magnesium sulfate, filtered and evaporated in vacuo to give $3.89 \mathrm{~g} \mathrm{(39 \% )}$ of $7 \mathbf{c}$ as a colorless liquid. ${ }^{13} \mathrm{C} \mathrm{NMR}(75.5 \mathrm{MHz}$, $\left.\mathrm{CDCl}_{3}\right): 158.4\left(1 \mathrm{C}, \mathrm{C}_{\mathrm{q}}\right), 157.9(1 \mathrm{C}, \mathrm{CH}), 104.8(1 \mathrm{C}, \mathrm{CH}), 10.9$ $\left(1 \mathrm{C}, \mathrm{CH}_{3}\right) .{ }^{1} \mathrm{H}$ NMR $\left(300 \mathrm{MHz}, \mathrm{CDCl}_{3}\right): 8.22(\mathrm{~s}, 1 \mathrm{H}, \mathrm{CH})$, 6.11-6.10 (d, $\left.1 \mathrm{H},{ }^{3} J=0.9 \mathrm{~Hz}, \mathrm{CH}\right), 2.24\left(\mathrm{~s}, 3 \mathrm{H}, \mathrm{CH}_{3}\right)$.

3,5-Dimethylisoxazole (7d) [25]. A solution of 2,4-pentanedione $(100.10 \mathrm{~g}, 1 \mathrm{~mol}, 103.2 \mathrm{~mL})$ and hydroxylamine hydrochloride $(74.70 \mathrm{~g}, 1.075 \mathrm{~mol})$ in water $(150 \mathrm{~mL})$ and ethanol $(100 \mathrm{~mL})$ was refluxed for $90 \mathrm{~min}$. The mixture was cooled to rt, poured onto ice $(200 \mathrm{~mL})$ and extracted four times with dichloromethane. The combined organic phases were dried over magnesium sulfate, filtered and evaporated. The resulting dark mixture was fractionated $\left(141^{\circ} \mathrm{C}\right)$ to yield $77.5 \mathrm{~g}(80 \%)$ of 7d as a colorless liquid. ${ }^{13} \mathrm{C}$ NMR $\left(75.5 \mathrm{MHz}, \mathrm{CDCl}_{3}\right): 168.2$ $\left(1 \mathrm{C}, \mathrm{C}_{\mathrm{q}}\right), 159.0\left(1 \mathrm{C}, \mathrm{C}_{\mathrm{q}}\right), 101.6(1 \mathrm{C}, \mathrm{CH}), 11.1\left(1 \mathrm{C}, \mathrm{CH}_{3}\right), 10.4$ $\left(1 \mathrm{C}, \mathrm{CH}_{3}\right) .{ }^{1} \mathrm{H}$ NMR $\left(300 \mathrm{MHz}, \mathrm{CDCl}_{3}\right): 5.76(\mathrm{~s}, 1 \mathrm{H}, \mathrm{CH})$, $2.317\left(\mathrm{~s}, 3 \mathrm{H}, \mathrm{CH}_{3}\right), 2.19\left(\mathrm{~s}, 3 \mathrm{H}, \mathrm{CH}_{3}\right)$. 
3,4,5-Trimethylisoxazole (7e) [26]. A mixture of 3 (20.55 g, $0.18 \mathrm{~mol})$, hydroxylamine hydrochloride $(12.50 \mathrm{~g}, 0.18 \mathrm{~mol})$ and water $(80 \mathrm{~mL})$ was stirred at $\mathrm{rt}$ for $24 \mathrm{~h}$. The solution was then extracted three times with chloroform and the combined organic layers were dried over magnesium sulfate and filtered. After removal of the solvent, the residue was distilled $\left(165^{\circ} \mathrm{C}\right)$ to yield $13.0 \mathrm{~g}(65 \%)$ of $7 \mathrm{e}$ as a colorless liquid. ${ }^{13} \mathrm{C}$ NMR $\left(75.5 \mathrm{MHz}, \mathrm{CDCl}_{3}\right): 163.4\left(1 \mathrm{C}, \mathrm{C}_{\mathrm{q}}\right), 159.0\left(1 \mathrm{C}, \mathrm{C}_{\mathrm{q}}\right), 108.2(1 \mathrm{C}$, $\left.\mathrm{C}_{\mathrm{q}}\right), 9.9\left(1 \mathrm{C}, \mathrm{CH}_{3}\right), 9.2\left(1 \mathrm{C}, \mathrm{CH}_{3}\right), 5.8\left(1 \mathrm{C}, \mathrm{CH}_{3}\right) .{ }^{1} \mathrm{H} \mathrm{NMR}$ $\left(300 \mathrm{MHz}, \mathrm{CDCl}_{3}\right): 2.01\left(\mathrm{~s}, 3 \mathrm{H}, \mathrm{CH}_{3}\right), 1.91\left(\mathrm{~s}, 3 \mathrm{H}, \mathrm{CH}_{3}\right), 1.61$ (s, $3 \mathrm{H}, \mathrm{CH}_{3}$ ).

3,5-Diphenylisoxazole (7f) [25]. A solution of 4 (4.49 g, $20 \mathrm{mmol})$ and hydroxylamine hydrochloride (1.74 g, $20 \mathrm{mmol})$ in water $(30 \mathrm{~mL})$ and ethanol $(20 \mathrm{~mL})$ was refluxed for $90 \mathrm{~min}$. The mixture was cooled to $\mathrm{rt}$, poured onto ice $(50 \mathrm{~mL})$ and extracted two times with dichloromethane. The combined organic phases were dried over magnesium sulfate, filtered and evaporated. The resulting solid was recrystallized from ether to yield $4.09 \mathrm{~g}(92 \%)$ of $7 \mathbf{f}$ as colorless crystals. ${ }^{13} \mathrm{C}$ NMR $\left(75.5 \mathrm{MHz}, \mathrm{CDCl}_{3}\right): 170.3\left(1 \mathrm{C}, \mathrm{C}_{\mathrm{q}}\right), 162.9\left(1 \mathrm{C}, \mathrm{C}_{\mathrm{q}}\right), 130.1(1 \mathrm{C}$, $\mathrm{CH}), 129.9(1 \mathrm{C}, \mathrm{CH}), 129.0\left(1 \mathrm{C}, \mathrm{C}_{\mathrm{q}}\right), 128.9(2 \mathrm{C}, \mathrm{CH}), 128.8$ $(2 \mathrm{C}, \mathrm{CH}), 127.4\left(1 \mathrm{C}, \mathrm{C}_{\mathrm{q}}\right), 126.7(2 \mathrm{C}, \mathrm{CH}), 125.7(2 \mathrm{C}, \mathrm{CH})$, 97.4 (1C, CH). ${ }^{1} \mathrm{H}$ NMR (300 MHz, $\left.\mathrm{CDCl}_{3}\right): 7.90-7.84$ (m, 4H, $\mathrm{CH}), 7.52$ (m, 6H, CH), $6.83(\mathrm{~s}, 1 \mathrm{H}, \mathrm{CH})$.

3-Phenyl-5-Methoxy-isoxazole (7g) [22]. A solution of 6 $(2.88 \mathrm{~g}, 16 \mathrm{mmol})$ and sodium methoxide $(7.78 \mathrm{~g}, 144 \mathrm{mmol})$ in methanol $(40 \mathrm{~mL})$ and THF $(40 \mathrm{~mL})$ was heated under reflux for $63 \mathrm{~h}$ and then concentrated. The residue was poured in iced water $(100 \mathrm{~mL})$, extracted with ether and washed with aqueous sodium carbonate to neutralize hydrochloric acid. The organic layer was dried over magnesium sulfate followed by removal of the solvent. The remaining solid was recrystallized from warm cyclohexane $\left(50{ }^{\circ} \mathrm{C}\right)$ to yield $1.57 \mathrm{~g}(56 \%)$ of $7 \mathrm{~g}$ as yellow crystals. ${ }^{13} \mathrm{C}$ NMR $\left(75.5 \mathrm{MHz}, \mathrm{CDCl}_{3}\right)$ : $174.4\left(1 \mathrm{C}, \mathrm{C}_{\mathrm{q}}\right), 163.9(1 \mathrm{C}$, $\left.\mathrm{C}_{\mathrm{q}}\right), 129.8(1 \mathrm{C}, \mathrm{CH}), 129.3\left(1 \mathrm{C}, \mathrm{C}_{\mathrm{q}}\right), 128.6(2 \mathrm{C}, \mathrm{CH}), 126.2$ $(2 \mathrm{C}, \mathrm{CH}), 75.1(1 \mathrm{C}, \mathrm{CH}), 58.7\left(1 \mathrm{C}, \mathrm{CH}_{3}\right) .{ }^{1} \mathrm{H}$ NMR: 7.75-7.72 $(\mathrm{m}, 2 \mathrm{H}, \mathrm{CH}), 7.42-7.39(\mathrm{~m}, 3 \mathrm{H}, \mathrm{CH}), 5.51(\mathrm{~s}, 1 \mathrm{H}, \mathrm{CH}), 3.96(\mathrm{~s}$, $\left.3 \mathrm{H}, \mathrm{CH}_{3}\right)$.

3-Phenyl-5-(trimethylsilyloxy)isoxazole (7h) [27]. To $2.72 \mathrm{~g}$ ( $25 \mathrm{mmol}, 3.2 \mathrm{~mL}$ ) of chlorotrimethylsilane, was added a mixture of 5 (3.22 g, $20 \mathrm{mmol})$ and hexamethyldisilazane (7.26 g, $45 \mathrm{mmol}, 9.5 \mathrm{~mL}$ ). The solution was heated at $120^{\circ} \mathrm{C}$ for 30 min and then concentrated. The resulting product was unstable and therefore used immediately.

NMR-photolyses of isoxazoles $7 \mathbf{a}-\mathbf{h}$ with aldehydes: General procedure. A solution of isoxazole $(0.05 \mathrm{mmol})$ and aldehyde $(0.1 \mathrm{M})$ in deuterated acetonitrile $(0.5 \mathrm{~mL})$ was transferred to a quartz NMR tube, degassed with argon and irradiated in a photo reactor (LZ-C4, $300 \mathrm{~nm}$ ) for $6 \mathrm{~h}$. The mixture was examined before and after irradiation by ${ }^{1} \mathrm{H}$ NMR spectroscopy.

\section{Photocycloaddition reactions of $7 \mathrm{e}$ with aryl substituted} aldehydes: General procedure. A solution of 7 e $(2.22 \mathrm{~g}$, $20 \mathrm{mmol})$ and the corresponding aldehyde $(20 \mathrm{mmol})$ in acetonitrile $(200 \mathrm{~mL})$ was transferred to a quartz vessel, mixed with potassium carbonate $(0.28 \mathrm{~g}, 10 \mathrm{~mol} \%)$ and degassed with nitrogen. The mixture was stirred and irradiated in a Rayonet photochemical reactor (RPR 208, lamps centered $300 \mathrm{~nm}$ ) at $-10^{\circ} \mathrm{C}$ for $48-72 \mathrm{~h}$. The resulting yellow solution was concentrated $\left(35^{\circ} \mathrm{C}\right)$ and extracted three times with ether. The combined organic layers were dried over magnesium sulfate and the solvent was evaporated. The solid residue was mixed with a little ethanol, stirred for $30 \mathrm{~min}$, filtered and recrystallized at $-10{ }^{\circ} \mathrm{C}$ from ethanol.

exo-1,4,5-trimethyl-6-phenyl-2,7-dioxa-3-azabicyclo[3.2.0]hept-3-en (9a). Yield: $50 \%$. ${ }^{13} \mathrm{C}$ NMR $\left(500 \mathrm{MHz}, \mathrm{CD}_{3} \mathrm{CN}\right): 163.6(1 \mathrm{C}, \mathrm{CN}), 138.9$ (1C, Ar-C), 129.3 (2C, Ar-C), 128.9 (1C, Ar-C), 126.2 (2C, Ar-C), 115.6 (1C, OCO), $86.4(1 \mathrm{C}, \mathrm{CO}), 63.7\left(1 \mathrm{C}, \mathrm{C}_{\mathrm{q}}\right), 19.1\left(1 \mathrm{C}, \mathrm{CH}_{3}\right), 11.1(1 \mathrm{C}$, $\left.\mathrm{CH}_{3}\right), 10.2\left(1 \mathrm{C}, \mathrm{CH}_{3}\right) .{ }^{1} \mathrm{H} \mathrm{NMR}\left(500 \mathrm{MHz}, \mathrm{CD}_{3} \mathrm{CN}\right)$ : $7.45-7.35\left(\mathrm{~m}, 5 \mathrm{H},{ }^{3} J=7.6 \mathrm{~Hz},{ }^{3} J=7.0 \mathrm{~Hz}, \mathrm{Ar}-\mathrm{CH}\right), 5.59$ (s, $1 \mathrm{H}, \mathrm{CH}), 2.05\left(\mathrm{~s}, 3 \mathrm{H}, \mathrm{CH}_{3} \mathrm{CN}\right), 1.60\left(\mathrm{~s}, 3 \mathrm{H}, \mathrm{CH}_{3}\right), 0.78(\mathrm{~s}, 3 \mathrm{H}$, $\mathrm{CH}_{3}$ ). Anal. calcd. for $\mathrm{C}_{13} \mathrm{H}_{15} \mathrm{NO}_{2}$ : C 71.87, H 6.96, N 6.45. Found: C 71.67, H 6.98, N 6.40. Colorless needles, unit cell parameters: $\mathrm{a}=9.3804(6), \mathrm{b}=14.8345(10), \mathrm{c}=9.080(6), \beta=$ 116.646(3), space group $P 2{ }_{1} / c$.

exo-1,4,5-trimethyl-6-(4'-methylphenyl)-2,7-dioxa-3-aza-bicyclo[3.2.0]hept-3-en (9b). Yield: $35 \% .{ }^{13} \mathrm{C} \mathrm{NMR}(75.5 \mathrm{MHz}$, $\left.\mathrm{CD}_{3} \mathrm{CN}\right): 163.7(1 \mathrm{C}, \mathrm{CN}), 138.8$ (1C, Ar-C), 136.1 (1C, Ar-C), 130.0 (2C, Ar-C), 126.4 (2C, Ar-C), 115.6 (1C, OCO), 86.6 $(1 \mathrm{C}, \mathrm{CO}), 63.8\left(1 \mathrm{C}, \underline{\mathrm{C}}_{\mathrm{q}}\right), 21.1\left(1 \mathrm{C}, \mathrm{CH}_{3}\right), 19.2\left(1 \mathrm{C}, \mathrm{CH}_{3}\right), 11.1$ $\left(1 \mathrm{C}, \mathrm{CH}_{3}\right), 10.3\left(1 \mathrm{C}, \mathrm{CH}_{3}\right) .{ }^{1} \mathrm{H}$ NMR $\left(300 \mathrm{MHz}, \mathrm{CD}_{3} \mathrm{CN}\right)$ : 7.26-7.24 (m, 4H, Ar-CH), $5.55(\mathrm{~s}, 1 \mathrm{H}, \mathrm{CH}), 2.35(\mathrm{~s}, 3 \mathrm{H}$, $\left.\mathrm{Ar}-\mathrm{CH}_{3}\right), 2.03\left(\mathrm{~s}, 3 \mathrm{H}, \mathrm{CH}_{3} \mathrm{CN}\right), 1.60\left(\mathrm{~s}, 3 \mathrm{H}, \mathrm{CH}_{3}\right), 0.79(\mathrm{~s}, 3 \mathrm{H}$, $\mathrm{CH}_{3}$ ). Anal. calcd. for $\mathrm{C}_{14} \mathrm{H}_{17} \mathrm{NO}_{2}$ : C 72.70, H 7.41, N 6.06. Found: C 72.71, H 7.45, N 6.08. Colorless needles, unit cell parameters: $a=17.196(2), b=5.9199(4), c=12.807(2), \beta=$ 109.944(4), space group $P 2{ }_{1} / c$.

exo-1,4,5-trimethyl-6-(3'-methylphenyl)-2,7-dioxa-3-aza-bicyclo[3.2.0]hept-3-en (9c). Yield: $65 \% .{ }^{13} \mathrm{C} \mathrm{NMR}(75.5 \mathrm{MHz}$, $\mathrm{CD}_{3} \mathrm{CN}$ ): 163.7 (1C, CN), 139.3 (1C, Ar-C), 139.0 (1C, Ar-C), 129.7 (1C, Ar-C), 129.3 (1C, Ar-C), 126.9 (1C, Ar-C), 123.4 $(1 \mathrm{C}, \mathrm{Ar}-\mathrm{C}), 115.7(1 \mathrm{C}, \mathrm{OCO}), 86.6(1 \mathrm{C}, \mathrm{CO}), 63.8\left(1 \mathrm{C}, \underline{\mathrm{C}}_{\mathrm{q}}\right)$, $21.4\left(1 \mathrm{C}, \mathrm{CH}_{3}\right), 19.2\left(1 \mathrm{C}, \mathrm{CH}_{3}\right), 11.1\left(1 \mathrm{C}, \mathrm{CH}_{3}\right), 10.3(1 \mathrm{C}$, $\left.\mathrm{CH}_{3}\right) .{ }^{1} \mathrm{H}$ NMR $\left(300 \mathrm{MHz}, \mathrm{CD}_{3} \mathrm{CN}\right): 7.35-7.13(\mathrm{~m}, 4 \mathrm{H}$, 
$\mathrm{Ar}-\mathrm{CH}), 5.54(\mathrm{~s}, 1 \mathrm{H}, \mathrm{CH}), 2.37$ (s, 3H, $\left.\mathrm{Ar}-\mathrm{CH}_{3}\right), 2.04(\mathrm{~s}, 3 \mathrm{H}$, $\left.\mathrm{CH}_{3} \mathrm{CN}\right), 1.60\left(\mathrm{~s}, 3 \mathrm{H}, \mathrm{CH}_{3}\right), 0.79\left(\mathrm{~s}, 3 \mathrm{H}, \mathrm{CH}_{3}\right)$. Anal. calcd. for $\mathrm{C}_{14} \mathrm{H}_{17} \mathrm{NO}_{2}$ : C 72.70, H 7.41, N 6.06. Found: C 72.55, H 7.39, $\mathrm{N}$ 6.09. Colorless needles, unit cell parameters: $\mathrm{a}=13.3045(8)$, $\mathrm{b}=6.9356(6), \mathrm{c}=17.5348(10), \beta=129.284(3)$, space group $P 2{ }_{1} / c$.

\section{References}

1. Griesbeck, A. G. In Handbook of Organic Photochemistry and Photobiology; Horspool, W. M.; Song, P.-S., Eds.; CRC Press: Boca Raton, FL, 1995; pp 550 and 755.

2. Griesbeck, A. G.; Mauder, H.; Stadtmüller, S. Acc. Chem. Res. 1994, 27, 70-75. doi:10.1021/ar00039a002

3. Griesbeck, A. G.; Buhr, S.; Fiege, M.; Schmickler, H.; Lex, J. J. Org. Chem. 1998, 63, 3847-3854. doi:10.1021/jo971767।

4. Kutateladze, A. G. J. Am. Chem. Soc. 2001, 123, 9279-9282. doi:10.1021/ja016092p

5. Griesbeck, A. G.; Abe, M.; Bondock, S. Acc. Chem. Res. 2004, 37, 919-928. doi:10.1021/ar040081u

6. Bach, T. Synthesis 1998, 683-703. doi:10.1055/s-1998-2054

7. Schreiber, S. L.; Hoveyda, A. H.; Wu, H. J. J. Am. Chem. Soc. 1983, 105, 660-661. doi:10.1021/ja00341a077

8. Griesbeck, A. G.; Fiege, M.; Lex, J. Chem. Commun. 2000, 589-590. doi:10.1039/b000578i

9. Bondock, S.; Griesbeck, A. G. Monatsh. Chem. 2006, 137, 765-777. doi:10.1007/s00706-006-0474-4

10. Griesbeck, A. G.; Bondock, S.; Lex, J. J. Org. Chem. 2003, 68 9899-9906. doi:10.1021/j0034830h

11. Griesbeck, A. G.; Bondock, S.; Lex, J. Org. Biomol. Chem. 2004, 2, 1113-1115. doi:10.1039/b401990c

12. Fuentes, J. A.; Maestro, A.; Testera, A. M.; Báñez, J. M. Tetrahedron: Asymmetry 2000, 11, 2565-2577. doi:10.1016/S0957-4166(00)00225-1

13. Scott, M. S.; Luckhurst, C. A.; Dixon, D. J. Org. Lett. 2005, 7, 5813-5816. doi:10.1021/ol052333c

14. Büchi, G.; Vederas, J. C. J. Am. Chem. Soc. 1972, 94, 9128-9132. doi:10.1021/ja00781a023

15. Kobayashi, T.; Kubota, T.; Ezumi, K.; Utsunomiya, C. Bull. Chem. Soc. Jpn. 1982, 55, 3915-3919. doi:10.1246/bcsj.55.3915

16. Singh, B.; Ullman, E. F. J. Am. Chem. Soc. 1967, 89, 6911-6916. doi:10.1021/ja01002a018

17. The crystallographic data for the isoxazole photoadducts $9 a, 9 b$, and 9c have been deposited with the Cambridge Crystallographic Data Centre as supplementary publications no. CCDC-795107 (9a), CCDC-795108 (9b), CCDC-795109 (9c).

18. Bouas-Laurent, H.; Dürr, H. Pure Appl. Chem. 2001, 73, 639-665. doi:10.1351/pac200173040639

19. Torssell, K.; Zeuthen, O. Acta Chem. Scand. 1978, 32B, 118-124. doi:10.3891/acta.chem.scand.32b-0118

20. Johnson, A. W.; Markham, E.; Price, R. Org. Synth. 1962, 42, 75-76.

21. Moreno-Mañas, M.; Pérez, M.; Pleixats, R. Tetrahedron 1994, 50, 515-528. doi:10.1016/S0040-4020(01)80773-0

22. Micetich, R. G.; Chin, C. G. Can. J. Chem. 1970, 48, 1371-1376. doi:10.1139/v70-226

23. Tarsio, P. J.; Nicholl, L. J. Org. Chem. 1957, 22, 192-193. doi:10.1021/jo01353a027

24. Sharma, S. C.; Torssell, K. Acta Chem. Scand. 1979, 33B, 379-383. doi:10.3891/acta.chem.scand.33b-0379
25. Fitton, A. O.; Smalley, R. K. Practical Heterocyclic Chemistry; Academic Press: London, 1968; pp 28-29.

26. Micetich, R. G.; Shaw, C. C.; Hall, T. W.; Spevak, P.; Fortier, R. A.; Wolfert, P.; Foster, B. C.; Bains, B. K. Heterocycles 1985, 23, 571-583. doi:10.3987/R-1985-03-0571

27. Ohba, Y.; Hishiwaki, T.; Akagi, H.; Nori, M. J. Chem. Res., Miniprint 1984, 2254-2262.

\section{License and Terms}

This is an Open Access article under the terms of the Creative Commons Attribution License

(http://creativecommons.org/licenses/by/2.0), which permits unrestricted use, distribution, and reproduction in any medium, provided the original work is properly cited.

The license is subject to the Beilstein Journal of Organic Chemistry terms and conditions:

(http://www.beilstein-journals.org/bjoc)

The definitive version of this article is the electronic one which can be found at: doi:10.3762/bjoc.7.18 